\title{
PRACTICALITY OF TEACHING LEARNING MATERIALS VOCATIONAL SKILLS FOR FACILITIES IN SLB 1 LIMA KAUM
}

\author{
Nella Kusuma $^{1}$, Fahmi Rizal $^{2}$, Asmar Yulastri ${ }^{3}$ \\ Universitas Negeri Padang, Indonesia \\ nellakusuma89@gmail.com
}

\begin{abstract}
This Development Research aims to develop a teaching material for vocational skills in fashion design designed to enhance student skills, as well as reveal the validity, practicality and effectiveness of the media. This study uses a Research and development development model that focuses on the IDI Method. Data analysis techniques used qualitative data through questionnaires and analyzed statistically. The results obtained from this research and development are as follows: (1) The learning module is a printed module for deaf students in Class $X$ Semester 1 in the Vocational Fashion Dress subject. (2) Practicality of fashion skills skills module for deaf students in Class X Semester 1 based on

Accepted: the teacher's response after going through practicality was declared practical May $27^{\text {th }} 2020$ with an average total of 69.6\%. (3) Practicality of fashion skills skills modules for deaf students in class $X$ semester 1 based on students' responses after going through practicality was declared practical with an average total of $65 \%$.

Keywords: Vocational teaching materials for fashion design, validity, practicality, effectiveness,
\end{abstract}

\section{INTRODUCTION}

This study aims to develop learning modules for deaf students in class X Semester 1 on subjects of vocational fashion skills in SLB Negeri 1 Lima Kaum and reveal the validity of the practicality and effectiveness of the media. The fashion skills module for deaf students in class X Semester 1 is designed to be able to improve the dexterity skills of deaf students to be able to fully understand the material available. This study uses the Research and Development Development Method which focuses on the IDI (Instructional Development Institute) Model which consists of three stages namely define, develop and evaluate. The type of data is primary data where data is obtained directly by material experts and media experts, teachers, and students. Data analysis techniques used are quantitative data analysis techniques provided by validators, teachers and students through a questionnaire that has been distributed and the results are analyzed statistically.

The results obtained from this research and development are as follows: (1) the fashion skills learning module for deaf students in class $\mathrm{X}$ semester 1 is a learning module in vocational skills in fashion. (2) Practicality of fashion skills modules for deaf students Class X Semester 1 is declared practical for teacher responses of $85.0 \%$ (3) Practicality of fashion skills modules for deaf students Class X Semester 1 is declared practical for student responses of $81.1 \%$. 
Special Education is one form of education organized by the government to produce independent human beings, graduates from SLB are expected to be able to be independent with expertise from the skills that have been provided by SLB schools in accordance with the interests of each student. This is in line with Republic of Indonesia Government Regulation No PP Number 17 Year 2010 article 130 paragraph (1) stipulates that "Special education for students with disabilities can be held at all lines and types of education at the level of primary and secondary education". Furthermore paragraph (2) provides flexibility that "The implementation of special education can be done through special education units, general education units, vocational education units, and / or religious education units". To achieve the objectives of these government regulations schools must create a good learning system by referring to the curriculum that has been implemented and in line with expectations.

SLB Negeri 1 Lima Special School using the 2013 Curriculum (K13) and assigns obligations to each student to choose 3 elective skills subjects. In the subject of fashion vocational skills for deaf students Class X Semester 1 there are basic competencies (3.1) making patterns, (3.2) making skirts, (3.3) making blouses. The learning process is carried out in a workshop where previously the teacher gave theories about patterns and various sewing techniques then students do the practice by being given a module which is a teaching material used as a guide during the learning process.

This condition has an impact not only in the teaching and learning process also has an impact on grades that are classified as low, this can be seen in the percentage of mid-semester class X exams majoring in TKJ in the academic year 2017/2018 still does not meet the standard of completeness set by the school.

Table 1.1 Mastery learning outcomes Odd semester subjects Vocational Skills for Dressing Class X SMALB-B students in SLB Negeri 1 Lima Kaum.

\begin{tabular}{lcccccc}
\hline BC 3.1 & \multicolumn{2}{c}{ BC 3.2} & \multicolumn{2}{c}{ BC 3.3} & Number of students \\
\hline$<75$ & $>75$ & $<75$ & $>75$ & $<75$ & $>75$ & KKM \\
\hline 2 & 8 & 8 & 2 & 4 & 6 & 10 \\
\hline
\end{tabular}

Based on this, teaching is needed with an approach that can lead to active interaction between teachers and students so that there is involvement in learning that is not abstract, does not require students to memorize facts but, a strategy that encourages students to construct knowledge in their minds alone. One alternative used to improve student learning achievement is the use of modules as learning resources. Based on problems and considerations.. 


\section{METHOD}

Research and development (Research and Development). Nana "Research and Development (R\&D) is a process or steps to develop an existing product, which can be accounted for ${ }^{1}$. According to Sugiyono "R\&D research can also be interpreted by the research and development method as a research method used to produce certain products and test the effectiveness of these products"2.

\section{RESULTS AND DISCUSSION}

The results obtained from this research and development are as follows: (1) The learning module is a teaching material on subjects of vocational fashion skills for deaf students in class X semester 1. (2) Practicality of fashion skills modules for deaf students in Class X Semester 1 was declared practical for teacher responses by $85 \%$ (3) Practicality of fashion skills skills modules for deaf students Kelasa X Semester 1 was declared practical for student responses by $81,1 \%$.

\section{Practicality Test}

The Practicality Test of the learning module is carried out to assess whether the developed learning module can be used to support the learning process at school or outside the school in the hope of achieving the learning objectives. After the product is applied to students, the practicality module of the learning module is tested through practicality test questionnaire teacher response and student response.

\section{Teacher Responses to Practical Modules Learning fashion skills for deaf students in class $\mathrm{X}$} semester 1.

Seeing the practicality of the learning module, the practitioner is assessed. Practicality data was obtained from a questionnaire filled out by the subject teachers in fashion vocational skills. The results of the teacher's response to the fashion skills learning module for deaf students in class X semester 1 can be seen in table 4.1 as;

\begin{tabular}{llll}
\hline No & \multicolumn{1}{c}{ Aspect } & & $(\%)$ Category \\
\hline 1 & Learning & 90,0 & Very Practical \\
\hline 2 & Material & 85,0 & Very Practical \\
\hline 3 & Display & 80,0 & Practical \\
\hline Teacher Response Average & 85,0 & \\
\hline \multicolumn{3}{c}{ Aspect Categories } & Very Practical
\end{tabular}

Table 4.1. Practicality Recapitulation Based on Teacher Response

\footnotetext{
${ }^{1}$ Nana Syaodih, Metode Penelitian Pendidikan. (Bandung: PT.Remaja Rosdakarya,cet kedua, 2005), 164

${ }^{2}$ Sugiyono. Qualitative ReD Quantitative Research Methods. (Bandung: Alfabeta. 2012).407
} 
The results of the analysis obtained an average practicality test results according to the fashion skills learning module according to the teacher that obtained a percentage value of $85.0 \%$ with the category of Very Practical.

Student Responses to the Practicality of Fashion Learning Skills Module for deaf students in class $\mathrm{X}$ semester 1. Through the fashion skills module for deaf students in class $\mathrm{X}$ semester 1 . The practicality of the learning module also requires input in the form of responses from students. This data is obtained after students use the learning module then students fill out the questionnaire provided. The results of the assessment of the practicality of the fashion skills learning module for deaf students in class $\mathrm{X}$ semester 1 are summarized in Table 4.2 as:

\begin{tabular}{llll}
\hline No & Aspect & $(\%)$ Category \\
\hline 1 & Learning & 83,4 & Very Practical \\
\hline 2 & Display & 80,9 & Practical \\
\hline 3 & Use of Module & 79,0 & Praktical \\
\hline \multicolumn{2}{l}{ Teacher Response Average } & 81,1 & \\
\hline \multicolumn{2}{l}{ Aspect Categories } & Very Practical \\
\hline \multicolumn{2}{l}{ Table 4.2. Practicality Recapitulation Based on Student Responses }
\end{tabular}

The results of the analysis obtained an average practicality test results according to fashion design skills according to students, obtained a percentage value of $81.1 \%$ with the category of Very Practical.

Based on Table 4.1 and Table 4.2 obtained the average practicality test results of the fashion skills learning module for deaf students in class X semester 1 based on data obtained from the teacher at $85.0 \%$ and from students at $81.1 \%$ included in the very practical category.

\section{CONCLUSION}

Based on the analysis of the results of research and discussion, it can be concluded that the development of the Learning Modules for fashion skills for deaf students in class X semester 1 that has been done has been declared very practical

\section{REFERENCES}

Abdul Majid. Learning Planning Developing Teacher Competency Standards. Bandung: Teen Rosdakarya. 2007. Ahmad Wasita. Ins and Outs of Deaf and Deaf and Learning Strategies. Yogyakarta: Javalitera. 2013. Anang Yuliawan. Psychology of Extraordinary Children. Department of Education and Culture. 2014. Apriyanti, M. The Analysis of Parents and School's Support Toward The Successful Work of Children with Intellectual Disability. Journal of International Conference on Special Education in Southeast Asia Region (ICSAR) 7th series 2017.1 (1): 252. 
Asri Budiningsih, C. Learning Message Design. Yogyakarta: UNY. Astati. 2001. Developing Life Skills of Children with Developmental Disabilities in City Public SLB. Semarang. Thesis. Taken from lib.unnes.ac.id accessed March 22, 2019.

Azhar Arsyad. Fruit of the Integration and Interconnection of Science and Religious Sciences. Hunafa: Journal of Studia Islamika. Vol 8, No. 1 June: 2011:1-25.

Azwar, S. Reliability and Validity (IV edition). Yogyakarta: Learning Library. 2014.

Basuki Wibawa and Farida Mukti. Teaching Media. Bandung: CV. Maulana. 2001.

Borg, W.R \& Gall, M.I.. In Education Research An Introduction, 4th. London: Longman Inc. 1983

Bulkia Uterus. The Contribution of Learning Method to the Learning Outcomes of Class X Students of Light Vehicle Engineering Skills Competency in the Technical Drawing Training Course at SMK Negeri 2 Solok. Automative Engeenering Edukative Journal. Vol.3 No 1. 2013.

Chaniago and Sirodjudin (1981). Vocational Education for Children with Tuna Grabita Taken from http://wwwpapahmamah.com/showthread.php?tDiakses February 16, 2019.

Daryanto and Aris Dwicahyono. Development of Learning Tools (Syllabus, RPP, PHB Teaching Materials). Yogyakarta: Gava Media. 2014.

Ministry of National Education. 2003. Module Writing Guidelines. Jakarta: Ministry of National Education. Sugiyono. Qualitative ReD Quantitative Research Methods. Bandung: Alfabeta. 2012.

Suharsimi Arikunto. Research Procedures. Jakarta: Rineka Cipta. 2012.

Suparno. Deaf Children Education (Orthoddactic Approach). Yogyakarta: Yogyakarta State University. 2001.

Surahman, Atwi. Instructional Design. Jakarta: Rineka Cipta. 2012.

Sukmadinata, Nana Syaodih, Metode Penelitian Pendidikan. Bandung: PT.Remaja Rosdakarya,cet kedua. 2005.

Sutjihati Somantri. Extraordinary Child Psychology. Bandung: Refika Aditama. 2006.

Tamimi. Skillful in self-heating and Sewing. Jakarta: Ministry of Education and Culture.1982. 